\title{
Factors Contributing to the Signing of the Abraham Accords
}

\author{
Bowen $\mathrm{Yi}^{*}$ \\ Yueyang No. 15 High School, Yueyang, Hunan 430602, China \\ *yibowen@cumt.edu.cn
}

\begin{abstract}
The signing of Abraham Accords can promote the realization of the common interests among countries to a certain extent. However, it may also trigger some conflicts among nations. This paper mainly analyzes the important factors contributing to the signing of the Abraham Accords from three perspectives: (1) the external factors -- the intervention of the US; (2) the internal factors -- the Arab and Israel's adaptation to the current international situations; (3) other factors -- the impact of COVID-19, the dictatorship of Arab leaders, and the personal political pursuits of the leaders from other nations. In this paper, Classical Realism is used to analyze the interests between countries, and the influence of some political decisions made by relevant state leaders is supplemented by Neo-realism. Additionally, in this paper, Neoliberalism and Constructivism are also employed to analyze the negotiations between national interests, including compromise, containment, and obstruction, as well as how negotiations promote the realization of common interests. It is expected that this paper can be of some reference significance to future research on the interests between nations as well as their cooperation and conflicts in the context of globalization.
\end{abstract}

Keywords: The Abraham Accords; Classic Realism; Neo-realism; Neo-liberalism; Constructivism; National Interests.

\section{Introduction}

The Israel-United Arab Emirates peace treaty, also named as Abraham Accords, which is signed on September 15th, 2020 is significant but controversial. This treaty is, on the one hand, described as the dawn of a new Middle East, while as a dangerous setback for peace on the other hand [1]. The signing of the Accords is based on the short-term interests exchange between the Arab states, in the context of the American Presidential Election and the global COVID-19 pandemic. Under such a complex background, although the signing of the Accords can promote the realization of common interests, it may also trigger new conflicts. For example, the Accords will not necessarily lead to the normalization of Arab-Israeli relations. Some external, internal, and other factors are contributing to the signing of this peace treaty. The external factor is mainly the intervention from the US. In addition to supporting Israel and its Arab Allies by reducing bilateral conflicts, America's purpose of promoting the signing of the Accords can be summarized as curbing and disturbing: suppressing Iran, containing and disconcerting China, and restricting Russia. In compliant with the international trend, the Arab and Israel desire to seize developmental opportunities and to avoid the Palestinian issues, which are the internal factors promoting the Accords' signing. Other factors, like the outbreak of the COVID-19, the dictatorship of Arab leaders, and the personal political pursuit of the leaders from other regions, contributed to the signing of the Accords as well. The paper combines the theories of Classical Realism [2, 3], Neo-realism [4], and Constructivism [5] to explore the factor(s) contributing to the signature of the Abraham Accords, which officially represents the normalization of relations between Israel with United Arab Emirates and Bahrain.

Classical realism theory shows that the relationship between countries is primarily affected by their common interests and has little significance with their political system and ideology [3]. Sovereign states are motivated by their national interests rather than allegiance to the common good. In the international community, such allegiance, the so-called common moral norm, does not exist [2]. From this perspective, the signing of the Accords is based on the maintenance and contention of different political actors for their respective interests. On this basis, Neo-realism adds the perspective that relevant leaders also influence national decisions. In this context, in the research, the personal political demands imposed by the President of the US and relevant leaders of Middle Eastern 
countries, especially important figures under the dictatorship, are also taken into consideration in the signing of the Accords [6]. One can refer to [7-15] and references therein for more details.

However, both Classical Realism and Neo-realism ignore that the national interests are not fixed and isolated but will change with the transformation of national identity and the change of international background. Moreover, with globalization, nation interests increasingly overlap and interweave with each other. However, the conflicts of national interests cannot fully explain the signing of the Accords and the changes in the situation in the Middle East. Therefore, in this paper, Neo-liberalism and Constructivism are also used to analyze the negotiations between national interests, including how compromise, containment, and disconcertment promote the realization of common interests. With the help of those theories, the research concludes that the successful signature of Abraham Accords is attributed to the interactions between multiple factors and behaviors.

\section{External Factors}

In addition to supporting Israel and its Arab Allies and reduce bilateral conflicts, the US's purpose of promoting the signing of the Accord can be summarized as containment and disconcertment.

\subsection{America's Suppression on Iran}

First of all, under the purpose of suppressing Iran, the US promoted the signing of the Accords. The regional situations are tense since the UN arms embargo on Iran is about to expire, and Iran is scaling back its commitments under the Iranian nuclear deal, and the anti-American sentiment is running high across Iran. In this process, America has acted as a bridge between the anti-Iranian agents in the Middle East, trying to unite the Arab and Jewish camps against Iran, who is "in the right place and at the right time" and "ready for revenge" [16].

Suppressing Iran is important to the US for several reasons. Since the fall of Saddam Hussein and the general decline of Arab nationalism, Iran has repositioned its strategic objectives to create a "Shiite Crescent" by expanding its regional influence. Iran supported the government of President Bashar Assad during the Syrian civil war when Iran paved the land road to Hizbullah in Lebanon. At the same time, Iran has established a stronger relationship with post-Saddam Iraq. Since 2006, the two countries have made several state visits, and Iran has become Iraq's largest trading partner and has supported its reconstruction efforts [17]. In return, Iraq expressed sympathy for Iran's nuclear program and passed a resolution to expel US troops from Iran [18]. Once the Shiite Crescent is formed, it will be in opposition to the Sunnite-centered Middle East policy advocated by the US, and Iran will also be able to threaten America's agents-Israel, Saudi Arabia, and to control the Strait of Hormuz with more strategic depth.

Aside from the above reason, Iran has been fighting US oil policy since its oil companies' nationalization in 1979. Iran, the fourth-largest oil producer in the world, allows oil to be traded in RMB, Euro, etc., impacting the dominance of the US dollar in the oil market. At the same time, Iran could take steps to fluctuating oil prices, with results contrary to American expectations. Gradually, Iran has become a challenge for the US to control the world oil markets and thus restrict other countries.

In recent years, due to its prosperous petroleum export trade, Iran gains support from China, establishes solid ties with Russia on issues such as the Syrian civil war, and forms a three-nation antiAmerican alliance, which has conducted an unprecedented and cooperated naval maneuver in September 2019. This year, Iran sent Venezuela the oil it needed and accepted military protection from Venezuela for its vessels. Besides, Iran has signed energy deals with Europe, which is in the interests of both parties, making countries like Britain, France, and Germany think twice before cooperating with the US to sanction Iran or signing agreements that harm Iran's interests. Trump government has announced that all UN sanctions against Iran have been restored, isolating it from most countries, including its European Allies, in a reflection of Iran's growing influence on US “turf." 
In short, due to Iran's oil exports and common agents in the Middle East, Iran has left its mark on America's adversarial countries and even its "backyard."

Using the Accords to suppress Iran is a long-term strategy, given Iran's negative impact on American interests: (1) The Accords prevent the US from imposing a head-on war on Iran and brings Iran's two main rivals together, further worsening Iran's external environment in the Middle East and leaving it with more limited space for advance and retreat. Therefore, it makes the parties who are eager to revenge for Mr. Suleiman difficult to find opportunities. If more Arab countries unite with the Jews, Iran will not dare to attack any Arab country for fear of the retaliation from both camps; (2) The Accords offer various benefits to the UAE (i.e., interactions with Israel and American incentives), which will tempt more Arab countries to join the Accords against Iran. This also convinces Arab countries that normalization of relations with Israel doesn't need to establish on the settlement of the Israeli-Palestinian conflict. In terms of nation interests, Arab states will soften their response to the next possible Israeli annexation, and will express their support for Palestine; (3) The accords can be considered an opportunity to ease Israel's opposition on American's military equipment sales in the Arab states, and thus further arm the Arab states (F-35s and Reaper UAV), and expose Iran to the maximizing costs of an attack; (4) The signing of the Accords is conducive to the cooperation of military intelligence and other military cooperation between Arab and Israeli camps. Arab states have claimed to their secret cooperating with Israel for years against Iran, and the signing of the Accords can make the cooperation become acceptable; (5) Finally, except for suppressing Iran, this accord also hurts its backers, China and Russia.

\subsection{America's Containment on China}

In addition to containing Iran, the US has also thrown many problems to China while promoting the Accords. First, in essence, the Accord is a curb on Iran, which is also a key node in China's "The Belt and Road" and a comprehensive strategic partner in geopolitics. According to James Stavridis, the former Supreme Commander of NATO, "the ensuing coalition "could create advanced early warning systems against Iranian missiles; a connected command and control network for missile defense; naval operations in the Red Sea, northern Indian Ocean, and Arabian Gulf; shared military technology; and a regular exchange of intelligence [19]." Besides, China has become Iran's largest importer $(\$ 18.9 \mathrm{~B}, 2018)$ and has invested heavily in the country, so China will instinctively fear that the Accords will harm its interests while suppressing Iran [20].

The Accords have also brought instability to China's "The Belt and Road." Hamas made its position clear immediately after the Accord was signed, and his recent talks have shown that the "betrayed" (Saeb Erekat) Palestinians are ready to unite in a desperate effort to confront Israel's looming annexation (Under the terms of the Accord, Israel agreed to suspend the annexation temporarily, not completely. Indeed, on October 14, Israel began a new round of annexation of the West Bank, knowing that it might no longer provoke a strong reaction from the Arab world), which may trigger a major war and greatly destabilize the Persian Gulf and the Strait of Hormuz, through which China passes on its maritime Silk Road [21]. Also, Iran and Iran-backed Hezbollah and Houthi groups may become increasingly aggressive, undermining the Silk Road's external environment. Therefore, "the Accords may not bring a new era of peace in the Middle East" [22], nor bring peace to "The Belt and Road."

Second, the signing of the Accord marks a further escalation of US intervention in the Arab region, which will harm China's interests. First, America has long resented Israel's co-operation with China. The Accords give the US some reasons to promise selling advanced F-35s to the UAE, raising Israeli concerns about its military supremacy. Whether the F-35 is sold or not may become a bargaining chip for the US. If Israel does not "comply", meaning their cooperation with America in cracking down on China, Russia, and Iran, America can then blackmail it by expanding its export of fighter jets to the UAE. American had blackmailed Israel in 2000. Under the pressure from America, Israel promised not to sell military equipment to China. Similarly, last year, under the pressure from the US, 
Israel banned Huawei's 5G technology and rejected China's bid for a $\$ 1.5$ billion desalination plant contract.

What also worries China is that, after signing the Accords, the US will be happy to sell better armaments such as the F-35 to the UAE, which may crowd out Chinese armaments at a political and functional disadvantage. This will not only reduce China's military equipment exports but also gradually break the solid military agreement between China and the UAE. In the past few years, despite repeated calls of the UAE and other Allies, the US reduced its core military sales to its allies while China's armaments (including drones) once maintained good momentum and profit in the markets of the UAE and other countries due to the cheap price, availability and fewer additional political conditions. However, since the signing of the Accords, the US has expanded its sales of advanced weapons (such as F-35 and Reaper drones), which may suppress China's armaments and reduce its interests. What's worse, the US may use its advanced armaments as a leverage to blackmail the UAE into reducing its interactions with China and undermining China's accumulated influence. The significance of the UAE to China lies not only in its oil but also in its significant status in the Arab world and even "The Belt and Road." Maintaining good relations with the UAE will help China to build a great national image in the Arab world and the third world. For example, in February 2019, under the opposition of the US, the UAE announced to enable Huawei's 5G technology, and after a month, Bahrain also made the same decision, claiming that "It is something we are proud to have," (Bahrain's Telecommunications Minister Kamal bin Ahmed Mohammed) - This domino effect is the same as it was at the time of the Abraham Accord (from a line to a large area).

Besides, the Accords have also created diplomatic dilemmas for China. China can gain more from its closer ties with Iran. China has the power to trade with the countries who are sanctioned by the US. Beijing would then become the leader of the revolt against the US, and more countries inclined to break away from the US will firmly join the lineup, shaking up the hegemony of the US (Venezuela and the current Philippines are examples). However, if China strengthens its ties with a besieged Iran, the US will find justification to obstruct countries such as Israel against the "The Belt and Road." Meanwhile, the UAE will be more embarrassed by its friendly relations with China.

Also, another paradox is that the normalization of relations between the UAE and Israel helps to contain Turkey's expansionist ambitions [23]. The country continues to obstruct China over the Issue of Xinjiang's Uighurs and has strong expansionist intentions, so it is necessary to attach importance to China's relations with the UAE and Israel. China used to be proud of its political ability to deal with Arab countries, Jewish countries, and Persian countries. However, balancing Iran, who desperately needs China's help, with Israel and the UAE will be difficult for Beijing today because so many interests are involved, and any misstep could destroy the Middle East diplomatic strategy that it has been building since the 1980s.

Besides, Beijing also needs to keep a close eye on the number of F-35s that the US sells to the UAE. If too many weapons are sold, Iran will be more repressed than Turkey, making it more difficult for Beijing to make diplomatic choices. If the sale of the F-35 to Arab countries could deter Turkey's expansionist attempts and make Israel, America's general agent in the Middle East, nervous, it would be an advantage to Beijing's; but if Iran is contained more forcefully than Turkey, Beijing will have reasons to be concerned. Meanwhile, China's relations with Israel are now good: some foreign media claimed that Mossad had "bought" the Chinese vaccine, but he claimed it was "stolen" to paralyze the US. Therefore, it will be difficult for China to support Iran greatly, or it will damage Sino-Israeli relations.

All in all, the US has brokered the UAE's relationship with Israel at the micro-level, but these micro-changes have important implications for the bigger picture. From a macro point of view, the US united Israel and the Arab world through the Accords to blend the four main camps in the Middle East (Arab, Jewish, Persian and Turkish) into three. America's Middle East policy will then be more focused on suppressing Iran and guarding against its rebellious ally, Turkey. At the same time, the US has reduced the macro complexity of the Middle East, which makes it more difficult for China to deal with it. China itself will be benefited from the Middle East's disconnected and dispersed 
microstructures, which are now much simpler and clearer. Beyond that, the last thing Beijing wants is that super-repressed Iran will turn to Turkey for support, and the Middle East may turn out to be two major camps on a macro level (in Americans' words: good countries and rogue countries).

It is difficult for the US itself to intervene in China's "The Belt and Road" construction to bypass the Pacific region, but it can worsen the external environment of "The Belt and Road" and harm Beijing's interests by bringing potential instability to the region. By pushing through the Accords, the US may be able to preserve its own long-term interests, thereby preserving its own interests and its super-influence in the Middle East.

\subsection{America's Restriction on Russia}

The US has kept eye on Russia as well as acting as an agent. If China is playing a game of interest with Israel, then the friendly relations between Russia and Israel are based on reality and history: Soviet Russia was the home of countless Jews. During the second world war, the Soviet Union defeated the Jews' greatest enemy - the Nazis - and avenged the Jews. After the collapse of the Soviet Union, hundreds of thousands of Soviet And Russian Jews migrated to Israel, forming the largest foreign community in Israel. It is estimated that more than $20 \%$ of Israelis now speak Russian fluently [24]; Meanwhile, to win votes, Prime Minister Netanyahu visited Russia many times, and the bilateral trade volume increased to 5 billion US dollars in 2019.

Russia also makes demands on Israel: Because Israel is a close ally of the US and Europe, Russia needs its support to return to the international stage and resume dialogue with the US and Europe without being completely isolated. At the same time, Israeli co-operation could help Russia save Pres. Assad's failing regime. Therefore, the Russia-Israel relationship is based on culture, economy, and strategy. However, Iran targeted by the Accords further complicates matters: Iran has aligned itself with Russia both in confronting America and protecting Pres. Bashar Assad's regime. Although the two countries have been at loggerheads over the S-300 incident, the oil, and the Syrian war, they have maintained contact under US sanctions. Therefore, Moscow will never abandon Iran, its "brother in need." It is just that the Abraham Accord pits Israel more against Iran, and whatever choice Russia makes, it will be on one side, which is the last thing Mr. Putin wants. And, unlike China, Russia has only considerable ties to two of the camps involved in the Accords and has fallen into diplomatic troubles in the European Union and elsewhere. Therefore, unlike Beijing, who can maneuver between UAE, Israel, and Iran, Moscow placed in a more disadvantaged international political position will have a narrow range of options -- easily lose the trust of one or both sides. That is why Russia would be loath to see a conflict between Iran and Israel and would be willing to act as a mediator between them in a war in Syria.

\section{Internal Factors: the Arab and Israel's Adaptation to the Current Situation}

\subsection{The UAE Hopes to Seize the Development Opportunity}

First, the UAE signed the Accords in pursuit of mutual interests with Israel. Historically, there is no conflict between the UAE and Israel, though Sheikh Zayed bin Sultan Al Nahyan, the UAE's first President at the time of its founding, called on every Arab country to bear "its responsibilities in the Israeli enemy". However, that was just a verbal promise and stood in vain at the moment when Arab nationalism faded. As time goes on, the real UAE sees an opportunity in Israel rather than the benefits of supporting the Palestinian cause of independence.

Second, the close ties between the UAE and Saudi Arabia, the leader of the Arab world, should also be taken into account. The UAE is Saudi Arabia's closest ally and a country protected by Saudi Arabia. The two countries have basically maintained a consensus on the general policy. Saudi Arabia normally entrusts the UAE to act as a vanguard for its own ideology in order not to annoy its Allies, the United States, and other big powers. Facing Huawei 5G technology, the United Arab Emirates was the first to announce its use. Seeing only condemnation from Washington, Saudi Arabia took heart and announced it would use Huawei 5G technology. 
With Mohammed bin Salman as the country's foreign-policy maker, Saudi Arabia prefers this surrogate or shadow diplomacy. Therefore, the UAE was most likely instructed by the Saudis to agree to the deal. Moreover, Saudi Arabia is well aware that its biggest enemy in the region is Iran, and the Accords aimed at Iran, so Saudi Arabia is more likely to sign the accords. The anti-Semitic clergy in Saudi Arabia has strong power. Moreover, the foreign policymakers of Saudi Arabia do not know how the big powers other than the US will react to the Accords, so they instruct the UAE, who will face less pressure at home and abroad, to "listen to the news," while waiting for the opportunity to act.

On top of that, the rise of Mohammed bin Salman could make Saudi foreign policy more realistic, more interest-based, and more ambitious to compete with rich regions, which has been proved by Saudi Arabia's involvement in the Yemen War and its isolation of Qatar. Therefore, behind the signing of the Accords by the UAE, there is also the shadow/manipulation role of Saudi Arabia. Saudi Arabia "cautiously welcomed" Abraham Accords, considering the Accords as positive and suggesting that the Accords opened its airspace to Israeli aircraft.

Finally, there is no doubt that the deal will bring huge benefits to the UAE. On the one hand, the Abraham Fund, announced by the US, Israel, and the UAE on October 20, will enable the UAE to obtain Israeli support in water-saving agriculture, seawater desalination and other technologies. The service sector in the UAE, which has been affected by COVID-19, will also be revitalized by Israeli tourists. The UAE will also benefit from cooperation with Israel in new energy, artificial intelligence, biopharma, and other fields. The UAE, on the other hand, will get American armaments to counter Iran and its agents. Besides, the UAE, a country centered on service sector, suffered economic damage during the COVID-19 outbreak. Due to a drop in the number of tourists, The UAE urgently needs to revitalize related industries, and the wealthy Israelis will be an excellent choice for the UAE.

\subsection{Israel Tries to Avoid Palestine Issues}

The Attitude of Arab Countries towards the Palestinian Issue Has Changed: The Accord was signed against the background of bypassing Palestine, which means that Arab countries can establish diplomatic relations with Israel based on not solving the Palestinian issues. Gradually, after discovering the great benefits of cooperating with Israel, the Arab states will adopt a more laissezfaire attitude towards Palestinian affairs in order not to harm their interests, thus legitimizing the potential annexation of Israel. Since then, Nasser's "3 Nots" may be a thing of the past ("Not to peace with Israel, not to negotiation with Israel, and not to recognition of Israel.").

The Situation in Palestine with Easy-Going Arab Leaders: Since Egypt's decline, the UAE has undoubtedly been an important member of the Arab world. If the relationship with UAE is well handled, other Arab countries may follow suit, forming a domino effect and isolating Palestine further.

\section{Other Factors}

\subsection{The Outbreak of COVID-19}

First, in early June, Israel allowed a UAE plane carrying medical supplies to land in the Gaza Strip. A few days later, Israeli Prime Minister Benjamin Netanyahu announced that health ministries in Israel and the UAE would work together on R\&D of medical programs, which aimed to combat COVID-19. The outbreak of COVID-19 provides an excuse for the cooperation between the two countries.

Additionally, COVID-19 has played a positive role in offsetting opposition to the Accords in some countries. Although Iran strongly opposed the Accords, it has had to reduce its attention to it because of the urgency of dealing with the epidemic at home. In this way, COVID-19 has reduced resistance to the accords. 


\subsection{Dictatorship and Democracy}

The Arab leaders who signed the Accords were all dictators, who did not represent their people and suppressed their dissidents. In accordance with Maryam al-Khawaja, human rights activist from Bahrain who is exiled in Denmark, "We're looking at oppressive, absolute monarchies who control everything, and therefore, what the monarchies do represent only themselves and not the populations." It turned out that Sadat had intensified his repression after signing the Camp David Accords against the Egyptians' wishes. Although he was later assassinated, the situation could have been very different in more authoritarian Gulf States, such as the UAE. Repression may force people to forget all this or suppress speech.

Therefore, although most Arabs have little chance of changing their hostility to Israel, their leaders will drown out their voices and create the illusion that they recognize it. The political systems of these countries enabled their leaders to sign the Accords unilaterally. They need to change their view of the world and prove that they are not just persecuting their dissidents.

\subsection{Personal Political Pursuits of the Leaders Who Signed the Accord}

a) Donald Trump in the US Election: In order to win the support of powerful Jewish voters and improve his status in the minds of Jewish voters, President Trump's ties to pro-Israel Jews go deeper than others. The biggest financial supporter behind his candidacy, Sheldon Adelson, is a fervent supporter of Israel, who is Jewish; Meanwhile, his supporters Stephen A. Schwarzman and Bernard Marcus, and even his own son-in-law are Jewish and pro-Israel.

Other factors, such as the fact that $64 \%$ of Jews belong to the Democratic Party, have kept Trump's support rate among Jewish voters below his average support rate. Under such circumstances, helping Israel is undoubtedly a good way to win support from Jewish voters and bring more of them into the Republican camp (According to the Pew Research Center, nearly 70\% of Jews say they have an emotional attachment to Israel).

Gain leverage in the election: Trump was once controversial due to his relations with the EU, China, Russia, and other countries, and was regarded as lacking diplomatic wisdom by some people. The signing of the Accords will undoubtedly change the stereotype of his diplomatic ability by others.

Trump has been criticized for his slow response to COVID-19, and he urgently needs to divert attention from his mismanagement.

b) Netanyahu in Crisis: Prime Minister Netanyahu faces domestic charges, and only a second term as a prime minister will keep him out of jail. Israel suffered from high diagnosis rates and high unemployment during the epidemic, and there are more and more protests against Netanyahu's mismanagement and he urgently needs to divert domestic attention.

\section{Conclusion}

Based on Classical realism and Neo-realism, the important factors influencing the signing of the Abraham Accords are discussed in this paper. The signing is based on the protection and competition of different political systems for their respective interests, and the personal political pursuits of leaders can also affect national decision-making. From the perspective of external factors, the US's intervention in the Arab-Israeli region is actually containment and disconcertment, to further suppress Iran, contain Chinese economic, technological, and military development, and limit Russian interests in the Arab-Israeli region. From the perspective of internal factors, the signing of the Accords enables the UAE to reach certain common interests with Israel, form closer international relations with Saudi Arabia, and bring huge economic benefits to the region. In this research, some personal political demands imposed by the President of the US and relevant leaders of Middle Eastern countries, especially some important figures who implement dictatorial measures, are also taken into consideration in the promotion of the signing. With the development of globalization, national interests are not constant. Conflicts of national interest cannot fully explain the signing of the Accords and the changing situation in the Middle East. Therefore, in this paper, Neo-liberalism and 
Constructivism are used to analyze the interaction between national interests, including how compromise, containment, and obstruction promote the realization of common interests of the ArabIsraeli region; that is, the successful signing of the Abraham Accord.

\section{References}

[1] D. Aviel, "Economic implications of the peace treaty between Egypt and Israel," Case W. Res. J. Int'1 L., vol. 12, pp. 57, 1980.

[2] H. J. Morgenthau, Political theory and international affairs: Hans J. Morgenthau on Aristotle's The Politics, Greenwood Publishing Group, 2004.

[3] H. A. Kissinger. Nuclear weapons and foreign policy, Routledge, 2019.

[4] K. N. Waltz, Theory of international politics, Waveland Press, 2010.

[5] A. Wendt, Social theory of international politics, Cambridge University Press, 1999.

[6] H. Kissinger, Diplomacy, Simon and Schuster, 1994.

[7] W. B. Quandt, Peace process: American diplomacy and the Arab-Israeli conflict since 1967, Brookings Institution Press, 2010.

[8] M. Riyād, The struggle for peace in the Middle East, Quartet Books Ltd, 1981.

[9] A. Cohen, Israel and the Arab world, London: WH Allen, 1970.

[10] R. Israeli, Man of defiance: a political biography of Anwar Sadat, Barnes \& Noble Imports, 1985.

[11] J. P. Lorenz, Egypt and the Arabs: foreign policy and the search for national identity, Westview Pr, 1990.

[12] E. Dowek, Israeli-Egyptian Relations 1980-2000, Psychology Press, 2001.

[13] D. Tschirgi, The American Search for Mideast Peace, Praeger Publishers, 1989.

[14] A. Sadat, In search of identity: An autobiography, HarperCollins Publishers, 1978.

[15] J. Carter, Keeping faith: Memoirs of a president, University of Arkansas Press, 1995.

[16] A. Ganji, "Who is Ali Khamenei: The worldview of Iran's supreme leader," Foreign Aff., vol. 92, pp. 24, 2013.

[17] C. Marcinkowski, Shi'ite identities: Community and culture in changing social contexts, LIT Verlag Münster, 2010.

[18] Information on https://www.npr.org/2020/01/06/793895401/iraqi-parliament-votes-to-expel-u-s-troopstrump-threatens-sanctions.

[19] J. Stavridis, watch officer's guide: a handbook for all deck watch officers/James Stavridis and Robert Girrier // Watch officer's guide: a handbook for all deck watch officers, Naval Institute Press, 2007.

[20] L. He, “China reportedly tops U.S.," As World's Largest Crude-oil Importer, 2015.

[21] J. H. Rosenthal, "Compromise and rotten compromises: A reflection on the Iran deal.".

[22] Z. Gan, G. Yu, X. He, and S. Li, "Numerical simulation of thermal behavior and multicomponent mass transfer in direct laser deposition of Co-base alloy on steel," International Journal of Heat \& Mass Transfer, vol. 104, pp. 28-38, 2017.

[23] M. Yegin, "Turkey's reaction to the coup in Egypt in comparison with the US and Israel," Journal of Balkan \& Near Eastern Studies, vol. 18, issue 4, pp. 407-421, 2016.

[24] W. B. Quandt, Camp David: Peacemaking and Politics. 2nd edition. The Brookings classic. Washington D.C. Brookings Institution Press, pp. 367, 2016. 
Volume 14 (2021)

\section{Appendix}

\begin{tabular}{|c|c|c|c|c|c|}
\hline \multicolumn{6}{|c|}{ Emotional Attachment to Israel } \\
\hline & $\begin{array}{c}\text { Very } \\
\text { attached }\end{array}$ & $\begin{array}{c}\text { Some- } \\
\text { what } \\
\text { attached }\end{array}$ & $\begin{array}{l}\text { Not very } \\
\text { attached }\end{array}$ & $\begin{array}{l}\text { Not at all } \\
\text { attached }\end{array}$ & $\begin{array}{l}\text { Don't } \\
\text { know }\end{array}$ \\
\hline & $\%$ & $\%$ & $\%$ & $\%$ & $\%$ \\
\hline NET Jewish & 30 & 39 & 22 & 9 & $1=100$ \\
\hline Jews by religion & 36 & 40 & 18 & 5 & $1=100$ \\
\hline Jews of no religion & 12 & 33 & 33 & 22 & $*=100$ \\
\hline Men & 33 & 39 & 20 & 8 & $1=100$ \\
\hline Women & 28 & 38 & 23 & 10 & $*=100$ \\
\hline Ages 18-49 & 25 & 36 & 28 & 11 & $1=100$ \\
\hline $18-29$ & 25 & 35 & 27 & 11 & $2=100$ \\
\hline $30-49$ & 25 & 36 & 29 & 10 & $*=100$ \\
\hline Ages $50+$ & 35 & 42 & 16 & 7 & $*=100$ \\
\hline $50-64$ & 32 & 42 & 18 & 7 & $0=100$ \\
\hline $65+$ & 38 & 41 & 14 & 7 & $1=100$ \\
\hline College grad+ & 31 & 38 & 23 & 8 & $*=100$ \\
\hline Post-grad degree & 32 & 37 & 23 & 8 & $*=100$ \\
\hline BA/BS & 31 & 38 & 22 & 8 & $*=100$ \\
\hline Some college & 28 & 41 & 22 & 8 & $1=100$ \\
\hline HS or less & 30 & 38 & 20 & 11 & $1=100$ \\
\hline Republican & 50 & 34 & 13 & 2 & $1=100$ \\
\hline Democrat & 25 & 40 & 25 & 10 & $*=100$ \\
\hline Independent & 30 & 38 & 21 & 10 & $*=100$ \\
\hline Orthodox & 61 & 30 & 4 & 5 & $1=100$ \\
\hline Ultra-Orthodox & 55 & 31 & 6 & 7 & $1=100$ \\
\hline Modern Orthodox & 77 & 22 & 1 & * & $1=100$ \\
\hline Conservative & 47 & 41 & 10 & 2 & $*=100$ \\
\hline Reform & 24 & 46 & 23 & 6 & $*=100$ \\
\hline No denomination & 16 & 33 & 33 & 18 & $1=100$ \\
\hline
\end{tabular}

Fig 1. Emotional Attachment to Israel

\begin{tabular}{|c|c|c|c|c|}
\hline \multicolumn{5}{|c|}{ Caring About Israel } \\
\hline \multirow[b]{3}{*}{ NET Jewish } & \multirow{2}{*}{$\begin{array}{c}\text { Essential } \\
\text { part of being } \\
\text { Jewish } \\
\%\end{array}$} & $\begin{array}{c}\text { Important } \\
\text { but not } \\
\text { essential }\end{array}$ & \multirow{2}{*}{$\begin{array}{c}\text { Not important } \\
\text { part of being } \\
\text { Jewish } \\
\%\end{array}$} & \multirow{2}{*}{$\begin{array}{c}\begin{array}{c}\text { Don't } \\
\text { know }\end{array} \\
\%\end{array}$} \\
\hline & & $\%$ & & \\
\hline & 43 & 44 & 12 & $1=100$ \\
\hline Jews by religion & 49 & 42 & 8 & $1=100$ \\
\hline Jews of no religion & 23 & 52 & 25 & $*=100$ \\
\hline Men & 39 & 47 & 14 & $1=100$ \\
\hline Women & 46 & 42 & 11 & $1=100$ \\
\hline Ages 18-49 & 35 & 48 & 16 & $1=100$ \\
\hline $18-29$ & 32 & 49 & 19 & $1=100$ \\
\hline $30-49$ & 38 & 48 & 14 & $1=100$ \\
\hline Ages $50+$ & 49 & 41 & 8 & $1=100$ \\
\hline $50-64$ & 47 & 43 & 10 & $1=100$ \\
\hline $65+$ & 53 & 39 & 7 & $1=100$ \\
\hline College gradt & 43 & 45 & 11 & $*=100$ \\
\hline Post-grad degree & 41 & 48 & 11 & $*=100$ \\
\hline $\mathrm{BA} / \mathrm{BS}$ & 45 & 43 & 11 & $*=100$ \\
\hline Some college & 44 & 42 & 13 & $1=100$ \\
\hline HS or less & 39 & 45 & 15 & $2=100$ \\
\hline Republican & 59 & 35 & 5 & $1=100$ \\
\hline Democrat & 38 & 48 & 14 & $1=100$ \\
\hline Independent & 43 & 44 & 12 & $1=100$ \\
\hline Orthodox & 55 & 35 & 10 & $1=100$ \\
\hline Ultra-Orthodox & 45 & 40 & 13 & $2=100$ \\
\hline Modern Orthodox & 79 & 18 & 3 & $0=100$ \\
\hline Conservative & 58 & 39 & 3 & $*=100$ \\
\hline Reform & 42 & 46 & 11 & $*=100$ \\
\hline No denomination & 31 & 50 & 18 & $1=100$ \\
\hline $\begin{array}{l}\text { Source: Pew Research } \\
\text { Q.ESh. Figures may no }\end{array}$ & $\begin{array}{l}\text { Center } 2013 \text { Sur } \\
\text { ot sum to } 100 \% \text { d }\end{array}$ & $\begin{array}{l}\text { Irvey of U.S. Je } \\
\text { due to roundin }\end{array}$ & $\begin{array}{l}\text { ws, Feb, 20-June } 13 \\
\text { g.. }\end{array}$ & 2013. \\
\hline PEW RESEARCH CENTE & & & & \\
\hline
\end{tabular}

Fig 2. Caring about Israel 